\title{
Downregulation of SFRP1 is a protumorigenic event in hepatoblastoma and correlates with beta-catenin mutations
}

\author{
Ivonne Regel ${ }^{1,2} \cdot$ Melanie Eichenmüller $^{2} \cdot$ Ujjwal Mukund Mahajan $^{1} \cdot$ Beate Hagl $^{2,3} \cdot$ Simone Benitz ${ }^{4}$. \\ Beate Häberle $^{2} \cdot$ Christian Vokuhl $^{5} \cdot$ Dietrich von Schweinitz ${ }^{2} \cdot$ Roland Kappler $^{2}$
}

Received: 25 October 2019 / Accepted: 11 March 2020 / Published online: 18 March 2020

(c) The Author(s) 2020

\begin{abstract}
Background Hepatoblastoma (HB) and pediatric hepatocellular carcinoma (HCC) are the most common malignant liver tumors in childhood. Both tumor types exhibit genetic and epigenetic alterations in the WNT/ $\beta$-catenin signaling pathway, which is a key regulator of liver progenitor cells in embryonic development. The tumors demonstrate a high rate of $\beta$-catenin mutations and gene expression changes of several WNT antagonists. However, the role of the WNT inhibitory factor secreted frizzled-related protein 1 (SFRP1) has not been addressed in pediatric liver cancer so far.

Results In our study, we investigated the gene expression level, DNA methylation status and functional relevance of SFRP1 in HB cell lines and in pediatric liver tumor patient samples. SFRPI was downregulated due to DNA promoter methylation in all tested HB cell lines. Overexpression of SFRPI in HB cell lines diminished tumor cell proliferation, colony formation and migration potential. In addition, the SFRP1-expressing HB cell lines showed reduced WNT/ $\beta$-catenin signaling pathway activity and decreased expression of WNT target genes. To evaluate the utility of SFRP1 as a biomarker in pediatric liver cancer, we determined the gene expression level and DNA methylation status of SFRP1 in 45 pediatric liver tumor patient samples. The correlation analysis of different clinical parameters and tumor characteristics revealed a significant correlation of reduced SFRPI expression with the presence of mutant $\beta$-catenin. The methylation status of SFRPI was furthermore associated to a pediatric liver tumor type with HCC-like characteristics, TERT mutations and an older age at diagnosis.

Conclusion Altogether, our data demonstrate that the epigenetic suppression of the WNT/ $\beta$-catenin antagonist SFRP1 has an important impact on the malignant behavior of HB cells. Although SFRPI methylation is a common event in HCC-like pediatric liver tumors, its potential as a prognostic or diagnostic biomarker needs to be further investigated.
\end{abstract}

Keywords Pediatric liver cancer $\cdot$ Hepatoblastoma $\cdot$ Hepatocellular carcinoma $\cdot$ Epigenetics $\cdot$ DNA methylation $\cdot$ WNT signaling $\cdot$ SFRP1 $\cdot$ DKK1 $\cdot$ WIF1 $\cdot$ APC

\section{Abbreviations}

HB Hepatoblastoma

HCC Hepatocellular carcinoma

NL Normal pediatric liver tissue

MSP Methylation-specific-PCR

Electronic supplementary material The online version of this article (https://doi.org/10.1007/s00432-020-03182-1) contains supplementary material, which is available to authorized users.

Roland Kappler

roland.kappler@med.uni-muenchen.de

1 Department of Medicine II, University Hospital, LMU Munich, Munich, Germany

2 Department of Pediatric Surgery, Dr. von Hauner Children's Hospital, Ludwig-Maximilians-University Munich, LMU Munich, Lindwurmstr. 2a, 80337 Munich, Germany 5-aza 5-aza-2'-deoxycytidine

pSFRP1 PcDNA3.1-SFRP1 plasmid

TLCT Transitional liver cell tumors

NSET Nested stromal-epithelial liver tumors

PRETEXT PRE-Treatment EXTent of tumor

EGCG Epigallocatechin-3-gallate

m Male

f Female

3 Chair and Institute of Environmental Medicine, UNIKA-T, Technical University of Munich and Helmholtz Zentrum Munich, Munich/Augsburg, Munich, Germany

4 Department of Molecular and Integrative Physiology, University of Michigan, Ann Arbor, MI, USA

5 Institute of Pathology, University Hospital Bonn, Bonn, Germany 


$\begin{array}{ll}\text { DOD } & \text { Died of disease } \\ \text { NED } & \text { No evidence of disease } \\ \text { E } & \text { Embryonal } \\ \text { F } & \text { Fetal } \\ \text { pure OS } & \text { Pure osteoid } \\ \text { C1 and C2 } & \begin{array}{l}\text { 16-gene signature cluster 1 and 2 (Cairo et al. } \\ \text { M }\end{array} \\ \text { 2008) } \\ \text { U } & \text { Methylated } \\ \text { nd } & \text { Unmethylated } \\ \text { na } & \text { No data } \\ & \text { Not applicable }\end{array}$

\section{Background}

Hepatoblastoma (HB) is the most common malignant liver tumor in children under the age of 4 years and its incidence has increased over the last decades (Kremer et al. 2014). Hepatocellular carcinoma (HCC) has also been described in the pediatric population, but the tumor occurs more rarely than HB and predominantly manifest in older children or young adults (Ng and Mogul 2018). Although the survival rates of pediatric $\mathrm{HB}$ and $\mathrm{HCC}$ have improved up to $80 \%$ over the last decades, due to advanced surgical techniques and chemotherapeutic treatments, there are still HB patient subgroups with a dismal prognosis (Tulla et al. 2015; Khanna and Verma 2018; Czauderna and Garnier 2018). Particularly, children presenting with non-resectable tumors, chemotherapy resistance, or metastasis show reduced survival rates (Czauderna et al. 2016). Consequently, a more profound understanding of the biology of $\mathrm{HB}$ will help to uncover mechanisms promoting cancer development and progression.

HBs often exhibit an epithelial or mixed morphological subtype and show two distinct transcriptomic profiles, which are classified as 16-gene signature cluster $\mathrm{C} 1$ or $\mathrm{C} 2$ (Perugorria et al. 2019). Although C1 and C2 HBs differ in their tumor characteristics, they exhibit common genetic aberrations affecting the WNT/ $\beta$-catenin/AXIN signaling (Cairo et al. 2008). The canonical WNT/ $\beta$-catenin signaling pathway regulates the proliferation, maturation and survival of liver progenitor cells in embryogenesis. Notably, the pathway is often constitutively activated in HB and HCC development (Russell and Monga 2018). Stabilizing mutations in the $\beta$-catenin (CTNNB1) gene occur with a frequency of up to $37 \%$ in $\mathrm{HCC}$ and $60-70 \%$ in $\mathrm{HB}$ and as a consequence, $\beta$-catenin accumulates in the nucleus and regulates the expression of target genes (Zucman-Rossi et al. 2015; Bell et al. 2017). Further genetic alterations involve loss-of-function mutations in the APC regulator of WNT signaling pathway (APC), AXIN1 and AXIN2 genes, which prevents a proteasomal degradation of $\beta$-catenin (Perugorria et al. 2019). Moreover, it was previously shown that the dickkopf WNT signaling pathway inhibitor $1(D K K l)$ is upregulated in $\mathrm{HB}$ patient samples, which might represent negative feedback mechanisms (Wirths et al. 2003). On the contrary, among the known WNT antagonists, the secreted frizzled-related protein 1 (SFRP1) is often downregulated in various cancer entities, which indicates that SFRP1 has tumor-suppressive functions (Vincent and Postovit 2017). Under physiological conditions, SFRP1 inactivates the canonical and non-canonical WNT/ $\beta$-catenin pathway by directly binding to WNT proteins or the frizzled receptor (Kawano and Kypta 2003). Thus, a downregulation of SFRP1 in HCC cells resulted in stimulated WNT signaling activity and increased tumor cell growth (Shih et al. 2007). Importantly, during breast and prostate cancer development SFRPI expression is lost due to epigenetic silencing, induced by an enrichment of DNA methylation in the promoter region (Lodygin et al. 2005; Lo et al. 2006). Notably, promoter methylation of SFRP 1 was also identified as a common event in adult HCC (Huang et al. 2007; Shih et al. 2006). Since SFRP1 suppression contributes to elevated $\mathrm{WNT} / \beta$-catenin signaling, which is a known characteristic of $\mathrm{HB}$ and $\mathrm{HCC}$, we were highly interested in the functional role of SFRP1 in pediatric liver cancers. Thus, we investigated the SFRPI DNA methylation status and gene expression levels in HB cell lines and primary pediatric liver tumor samples. Overexpression of SFRPI in HB cell lines resulted in an inhibition of tumor cell growth, colony formation and migration and a decrease in WNT/ $\beta$-catenin signaling activity. Moreover, $S F R P 1$ promoter methylation and transcriptional silencing was identified in a subset of primary pediatric liver tumors. Our findings indicate that the epigenetic suppression of SFRP1 represents an alternative mechanism for enhancing $\mathrm{WNT} / \beta$-catenin signaling in the development of pediatric liver cancer, particularly in children diagnosed at older ages.

\section{Methods}

\section{Patients}

Liver tumor specimens of 45 patients and matching normal liver tissue from seven patients (N110, N146, N198, N175, N227, N253, N612) were obtained from pediatric patients undergoing surgical resection in the Department of Pediatric Surgery, University Hospital, LMU Munich, Germany. Each patient gave written informed consent and the study protocol was approved by the Committee of Ethics, LMU Munich. Clinicopathological parameters and experimental data of all patient samples are listed in the Supplementary Table 1. Experimental data of SFRPI expression were categorized into low $(<1)$ and high $(>1)$ and correlated to different clinicopathological parameters. A similar correlation analysis was 
performed for the SFRP1 methylation status ( $M$ methylated, $U$ unmethylated).

\section{Cell culture and DNA methylation inhibitor treatment}

The hepatoblastoma cell lines HuH-6 (RRID:CVCL_4381), HepT1 (RRID:CVCL_G003), Hep-T3 (RRID:CVCL_ G004), and HepG2 (RRID:CVCL_0027) were cultured in RPMI 1640 growth media (Gibco, Thermo Fischer Scientific, Germany), supplemented with $10 \%$ fetal calf serum, $100 \mathrm{U} / \mathrm{mL}$ penicillin, and $100 \mu \mathrm{g} / \mathrm{mL}$ streptomycin, at $37^{\circ} \mathrm{C}$ in a humidified chamber with a saturated atmosphere containing $5 \% \mathrm{CO}_{2}$. Cells were passaged at a confluency of $80-90 \%$ with $0.05 \%$ trypsin $(v / v)$ and $0.2 \%$ EDTA $(w / v)$ (Sigma-Aldrich, Germany) in Dulbecco's phosphate-buffered saline (PBS). For gene expression and methylation analysis Huh-6 and Hep-T3 cells were treated with $0.5 \mu \mathrm{M}$ 5-aza-2'-deoxycytidine (5-aza; Sigma-Aldrich, Germany), HepT1 and HepG2 cells with $1.25 \mu \mathrm{M} 5$-aza or solvent for 3 and 5 days.

\section{Cell transfection}

HuH-6, HepT1 and HepG2 cells $\left(5 \times 10^{5}\right.$ cells/six-well plate $)$ were transfected with $1 \mu \mathrm{g}$ DNA of the pcDNA3.1/V5-HisA control vector (\#V81020, Thermo Fischer Scientific, Germany) or the pcDNA3.1-SFRP1 (pSFRP1) expression vector containing full-length SFRPI cDNA (Fukui et al. 2005) using FuGene 6 transfection reagent (Roche Diagnostics, Germany) according to the manufacturer's protocol. For stable transfection, cells were incubated in selection media $24 \mathrm{~h}$ after transfection containing $200 \mu \mathrm{g} / \mathrm{ml}$ G418 (SigmaAldrich, Germany). Two weeks after G418 selection, resistant colonies were picked and cultured under standard medium conditions.

\section{Cell viability assay}

2000 stably or transiently transfected HuH-6, HepT1 and HepG2 cells were seeded in a 96-well plates in RPMI 1640 growth media and cell proliferation was measured at the indicated time points using the Cell Proliferation Kit I (Roche Diagnostics) according to the manufacturer's protocol. The absorbance of the colorimetric reaction was quantified on the GENios reader (Tecan, Switzerland) by measuring at a wavelength of $595 \mathrm{~nm}$. Cell growth was normalized to the zero hour time points.

\section{Colony formation assay}

5000 stably transfected HuH-6 and HepG2 cells were seeded in a six-well plate. Cells grew for 10 days in RPMI 1640 growth media. After methanol fixation, cells were stained with $0.05 \%$ crystal violet in $20 \%$ methanol and washed with tap water. Colonies were counted and are represented as number of colonies per well.

\section{Cell migration assay}

Stably transfected HuH-6 cells were seeded into six-well plates and grown as confluent monolayer. A wound of approximately $1 \mathrm{~mm}$ was inflicted to the cell monolayer using a pipette tip. The cells were washed twice with PBS to remove detached cells and incubated for additional $72 \mathrm{~h}$ in $1 \%$ FCS starved RPMI 1640 growth media to diminish cell proliferation. Images were taken at $0,24,48$ and $72 \mathrm{~h}$ after scratching and the wound widths were measured and quantified with ImageJ (Rasband, W.S., ImageJ, US National Institutes of Health, Bethesda, USA). Cell migration was normalized to the zero hour time points.

\section{TOP/FOP assay}

To measure the activity of the canonical WNT/ $\beta$-catenin pathway, we used the TOP/FOP-flash promoter assay (Millipore, Germany). $1 \times 10^{5}$ stably transfected HuH-6, HepT1 and HepG2 cells were seeded in a 12-well plate and cotransfected with FuGene 6 transfection reagent (Roche Diagnostics) using the following plasmids: pTOP (Firefly-Luciferase reporter plasmid containing several TCF binding sites) or pFOP (Firefly-Luciferase reporter plasmid containing mutated TCF binding sites) together with pRL-TK (RenillaLuciferase control plasmid to normalize transfection efficiency). The luciferase activity was measured with the DualGlo $^{\mathrm{TM}}$ Luciferase Assay System (Promega, Germany) $48 \mathrm{~h}$ after transfection according to the manufacturer's protocol on the GENios microplate reader (Tecan).

\section{Immunofluorescence staining}

Staining was performed according to standard protocol using $\beta$-catenin (D10A8) antibody (\#8480, cell signaling, USA). Negative control was performed with secondary antibody only (data not shown).

\section{Immunoblot analysis}

Immunoblot analysis was performed according to the manufacturer's protocol, with the exception that blocking and first antibody (SFRP1 (D5A7) \#3534, cell signaling, USA; 
GAPDH, H86504M, Meridian Life Science, USA) incubation was done in 5\% BSA/TBS-T buffer. Secondary antibody was incubated in 5\% milk/TBS-T.

\section{Quantitative real-time PCR (qRT-PCR)}

Total RNA was extracted using TriReagent (Sigma-Aldrich, Germany) according to the manufacturer's protocol. Two micrograms of RNA was transcribed into cDNA using random hexamer primer and SuperScript ${ }^{\mathrm{TM}}$ II Reverse Transcriptase (Thermo Fischer Scientific, Germany). Quantitative RT-PCR was performed in doublets using iTaq-SYBR Green-Supermix (Bio-Rad, Germany) and the Master cycler ep gradient (Eppendorf, Germany) as previously described (Eichenmuller et al. 2009). Gene expression primer are provided in Supplementary Table 2. Expression levels were normalized to the housekeeping gene TATA-box binding protein $(T B P)$ and the fold change was calculated according to the $\Delta \Delta \mathrm{Ct}$ method in relation to the expression level of normal liver tissue. An expression level $<1$ represents a low and $>1$ a high expression.

\section{Methylation analyses}

Genomic DNA was isolated by phenol and chloroform extraction following standard procedures. As a positive control for methylated DNA, genomic DNA of a healthy donor was artificially methylated using the $\mathrm{CpG}$ methyltransferase M. SssI (Thermo Fischer Scientific, Germany) according to the manufacturer's instructions. As a negative control for unmethylated DNA, HuH-6 cells were treated with $0.5 \mu \mathrm{M}$ 5-aza-2'-deoxycytidine (5-aza; Sigma-Aldrich, Germany) for $72 \mathrm{~h}$ and genomic DNA was isolated. Genomic DNA was bisulfite-treated using the EpiTect ${ }^{\circledR}$ Bisulfite Kit (Qiagen, Hilden, Germany) according to the manufacturer's protocol. The methylation status of APC, DKK1, SFRPI and WIF1 was analyzed by methylation-specific-PCR (MSP). MSP primer are provided in Supplementary Table 2 (Aguilera et al. 2006; Esteller et al. 2000). MSP primer design and PCR conditions were previously described (Eichenmuller et al. 2009). PCR products were visualized on a $1.5 \%$ agarose gel.

\section{Chromatin immunoprecipitation}

HuH-6, HepT1 and HepG2 cells were treated with $1.5 \mu \mathrm{M}$ 5-aza, $1.5 \mu \mathrm{M}$ 5-aza plus $0.5 \mu \mathrm{M}$ Vorinostat (SAHA) (SML0061, Sigma-Aldrich, Germany) or dissolvent (DMSO, 1:1000) for 3 days. Chromatin immunoprecipitation was performed as previously described (Benitz et al. 2019). Here, we used the following antibodies: anti-H3K27ac (AcetylHistone H3 (Lys27) (D5E4), \#8173, Cell Signaling, USA), or IgG control (sc-2027, Santa Cruz Biotechnology, USA). Pull-down was done with Protein A agarose/salmon sperm DNA (Merck Millipore, Germany). After reverse crosslinking, DNA was purified with the Qiaquick ${ }^{\circledR}$ PCR Purification Kit (Qiagen) and two genomic areas around transcriptional start side of $S F R P 1$ were amplified and quantified by qRTPCR. Analysis of the EPCAM promoter was included as quality control to ensure specific enrichment of the activating histone modifications. Primer sequences are listed in Supplementary Table 2. Sample values were calculated according to the percent input method.

\section{Statistical analysis}

Data are presented as mean \pm SEM. Statistical significance was determined by two-tailed, unpaired Student's $t$ test, one-way ANOVA with Dunnett's multiple comparisons test or Chi-square test as indicated in the figure legends using GraphPad Prism 8 software (GraphPad Software Inc.) or R 2.1.0 (https://cran.r-project.org/src/base/R-2/R-2.1.0.tar. gz) and R-studio Version 1.1.442. A two-sided significance of $p<0.05$ was used throughout, $* p<0.05, * * p<0.01$, $* * * p<0.001, * * * * p<0.0001$.

\section{Results}

\section{Promoter methylation causes SFRP1 silencing in human HB cell lines}

Although the WNT/ $\beta$-catenin signaling pathway is often constitutively activated in liver cancer, due to stabilizing $\beta$-catenin mutations, previous data indicate that an additional suppression of the WNT antagonist, particularly of SFRP1, through epigenetic mechanisms is an important event in cancer formation (Kaur et al. 2012). To analyze the gene expression status of the known WNT antagonists $A P C, D K K 1, S F R P 1$ and WIFl in HB, we selected the HB cell lines HuH-6, HepT1, Hep-T3 and HepG2 and compared the expression levels to normal pediatric liver tissue (NL) (Fig. 1a). Here, $A P C$ and SFRPI were downregulated in all four HB cell lines. In contrast, $D K K 1$ and WIFI showed a heterogeneous expression pattern, with an increased expression of DKK1 in HuH-6, HepT1 and Hep-T3 and of WIF 1 in Hep-T3 cells (Fig. 1a). Next, we investigated whether the gene expression of APC, DKK1, SFRPI and WIF1 is epigenetically controlled by DNA promoter methylation. For this, we performed methylation-specific-PCR (MSP) after bisulfite treatment of DNA isolated from HB cell lines and identified that all four HB cell lines demonstrated a strong 
a

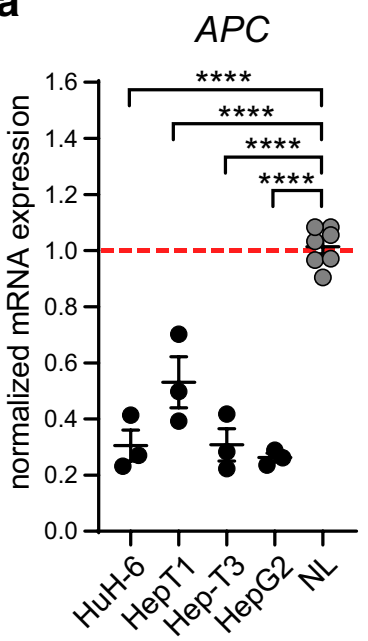

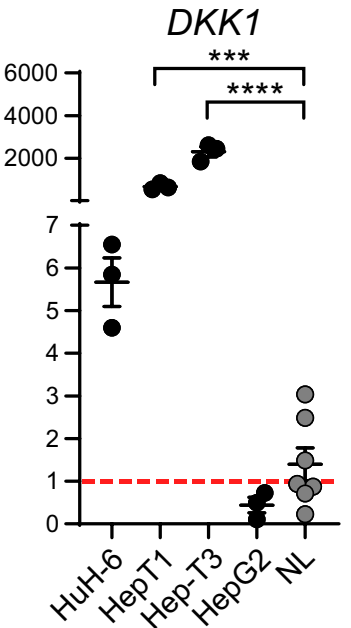

b

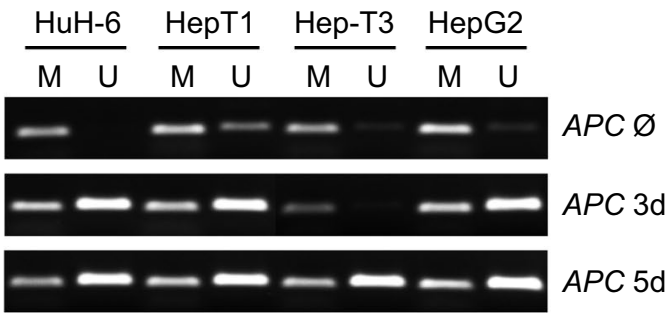

$\frac{\text { HuH-6 }}{M U} \frac{\text { HepT1 }}{M U} \frac{\text { Hep-T3 }}{M U} \frac{\text { HepG2 }}{M U}$

$-\quad--\infty-$

SFRP1 Ø

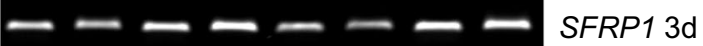

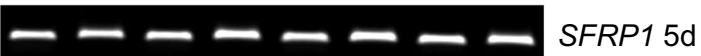

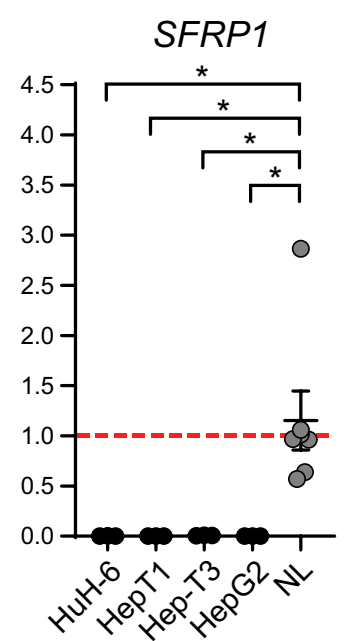

WIF1
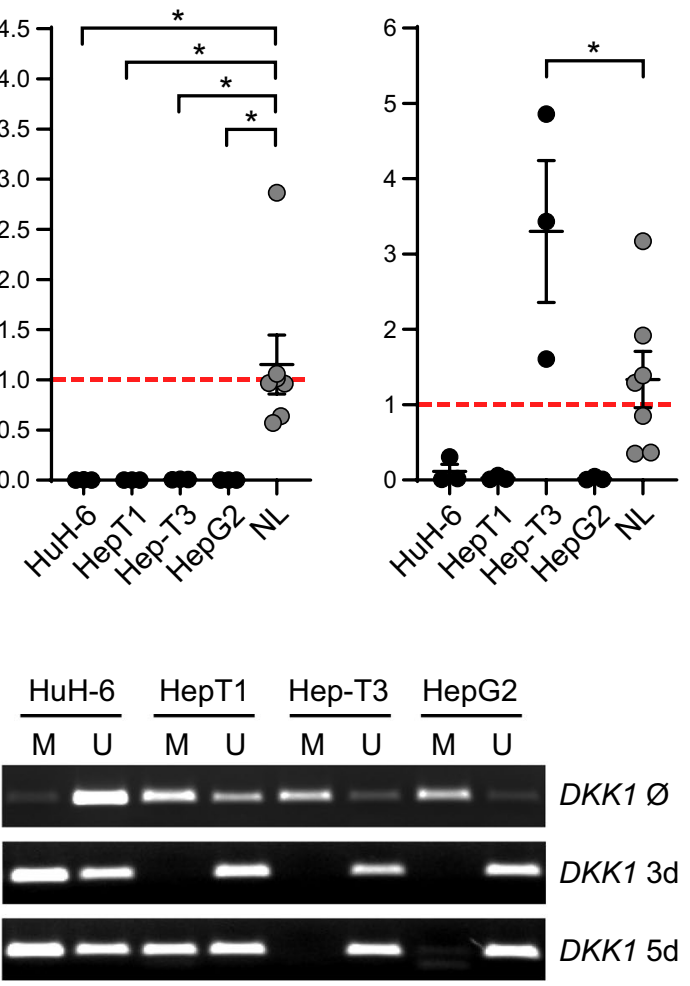

$\frac{\text { HuH-6 }}{M U} \frac{\text { HepT1 }}{M U} \frac{\text { Hep-T3 }}{M \quad U} \frac{\text { HepG2 }}{M U}$

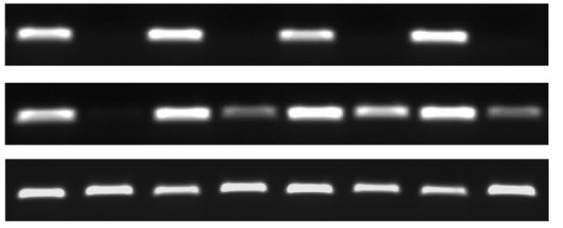

WIF1 Ø

WIF1 3d

WIF1 5d
C

\begin{tabular}{|c|c|c|c|c|c|c|}
\hline & \multicolumn{2}{|c|}{ HuH-6 } & & \multicolumn{3}{|c|}{ НерТ1 } \\
\hline & & $\begin{array}{ll}3 d & 5 d\end{array}$ & & $\bar{\varnothing}$ & $3 d$ & $\overline{5 d}$ \\
\hline$A P C$ & & & $A P C$ & & & \\
\hline$D K K 1$ & & & DKK1 & & & \\
\hline$S F R P 1$ & & & SFRP1 & & & \\
\hline WIF1 & & & WIF1 & & & \\
\hline
\end{tabular}

Fig. 1 Promoter methylation causes SFRP1 silencing in human HB cell lines. a mRNA expression of APC, DKK1, SFRP1 and WIF1 in HuH-6, HepT1, Hep-T3, and HepG2 and normal liver (NL, $n=7$ ) was determined by qRT-PCR $(n=3)$ and calculated as normalized mRNA expression (fold change) to normal liver controls. b DNA methylation status ( $M$ methylated, $U$ unmethylated) of APC, DKK1, SFRP1 and WIF1 promoter regions in HuH-6, HepT1, Hep-T3, and HepG2 after solvent $(\varnothing), 3$ days (3d) and 5 days (5d) 5-aza treatment was

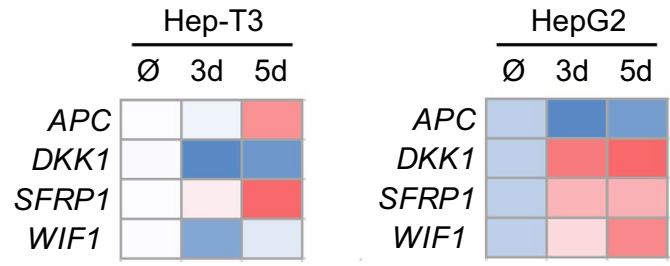

$\log 2$ relative gene expression

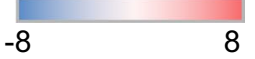

conducted by MSP. c mRNA expression of APC, DKK1, SFRP1 and WIF1 in HuH-6, HepT1, Hep-T3, and HepG2 after solvent (Ø), 3 days (3d) and 5 days (5d) 5 -aza treatment $(n=3)$ was determined by qRT-PCR and summarized as $\log _{2}$ relative gene expression in heatmaps. All data are represented as mean \pm SEM; $p$ values were calculated by one-way ANOVA with Dunnett's multiple comparisons test; $* p<0.05, * * * p<0.001, * * * * p<0.0001$ 
a

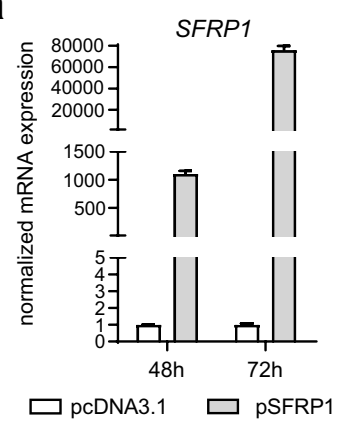

C

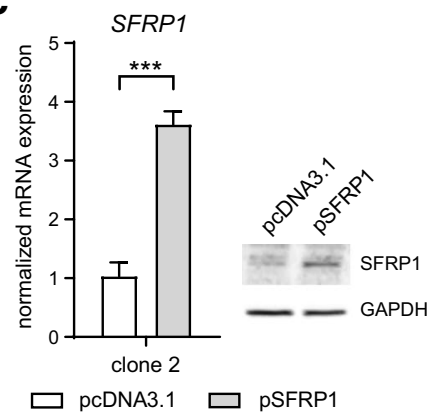

e

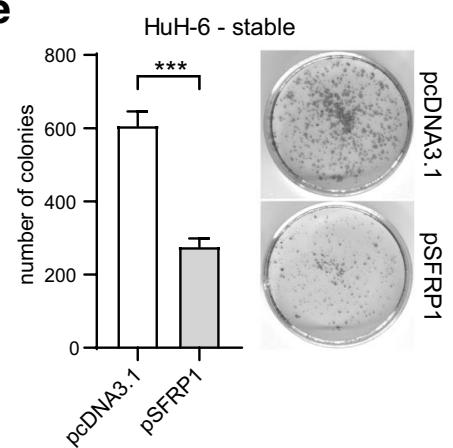

g

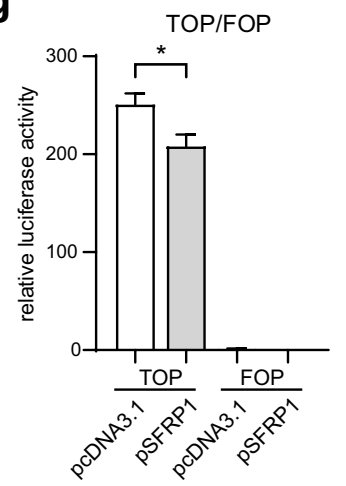

h

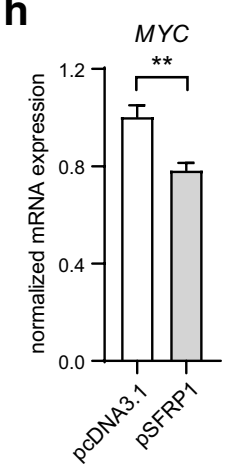

b

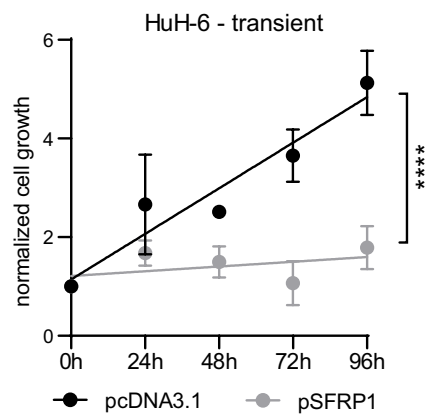

d

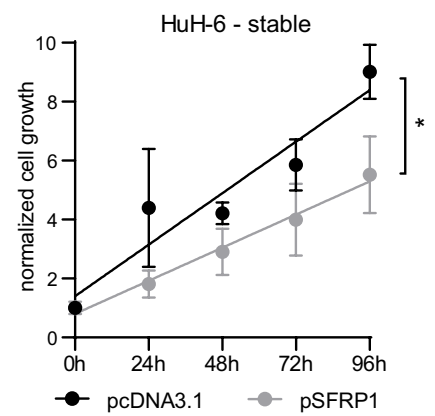

f
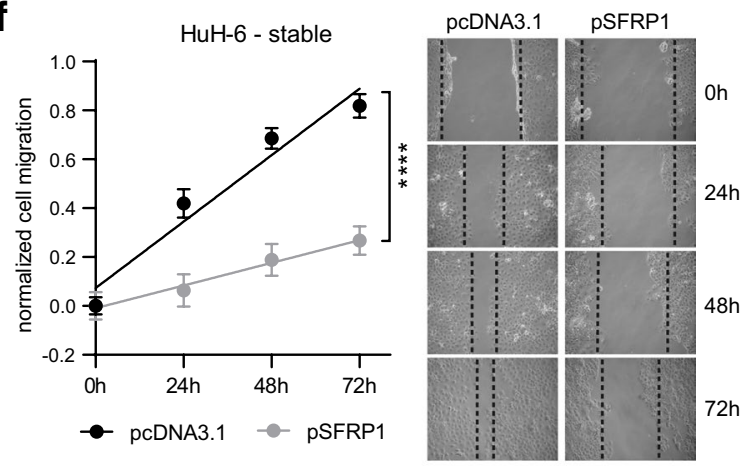

i
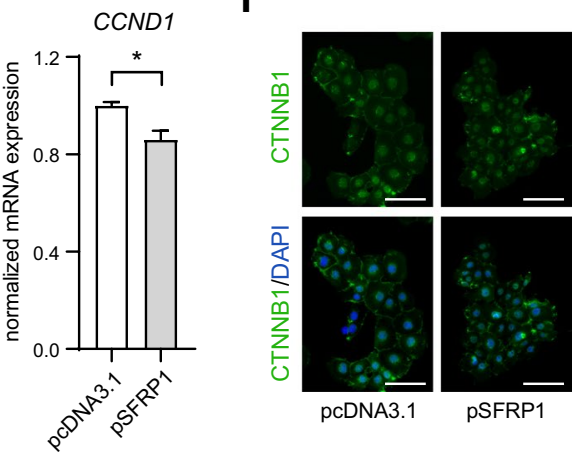

DNA promoter methylation of the APC, DKK1, SFRP1 and WIFI genes, with an exception for $D K K 1$, which was unmethylated in HuH-6 cells (Fig. 1b). Treatment with the DNA methylation inhibitor 5-aza-2'-deoxycytidine (5-aza) for 3 and 5 days revealed a strong DNA demethylation of the analyzed promoter areas in all cell lines (Fig. 1b). However, 5-aza treatment did not affect $A P C$ expression.
DKKI and WIF1, which show originally a high expression in HepT1 and/or Hep-T3 cells, were unexpectedly downregulated after 5-aza treatment (Fig. 1c). Interestingly, only the demethylation of the SFRP1 promoter was associated with a consistent restoration of gene expression in all four HB cell lines (Fig. 1c). Immunoblot analysis of 5-aza-treated HuH6, HepT1 and HepG2 cells revealed increased SFRP1 
4Fig. 2 Restored SFRP1 expression affects WNT signaling activity and HB tumor cell characteristics. a mRNA expression of SFRP1 in transient pcDNA3.1- and pSFRP1-transfected HuH-6 cells after 48 and $72 \mathrm{~h}$ was determined by qRT-PCR and calculated as normalized mRNA expression (fold change) to pcDNA3.1 control $(n=2)$. b Cell growth of transient pcDNA3.1- and pSFRP1-transfected HuH-6 cells was assessed by MTT assay at indicated time points. Values were normalized to zero hour time point and shown as mean $\pm \operatorname{SEM}(n=2)$. Slope difference was analyzed by linear regression, $* * * * p<0.0001$. c mRNA expression and representative immunoblot image of SFRP1 in stable pcDNA3.1- and pSFRP1-transfected HuH-6 cell clone 2. GAPDH served as loading control in immunoblot analysis $(n=2)$. Gene expression was determined by qRT-PCR and calculated as normalized mRNA expression (fold change) to pcDNA3.1 control $(n=3)$. d Cell growth of stable pcDNA3.1- and pSFRP1-transfected HuH-6 cells was assessed by MTT assay at indicated time points. Values were normalized to zero hour time point and shown as mean \pm SEM $(n=4)$. Slope difference was analyzed by linear regression, ${ }^{*} p<0.05$. e Representative pictures and quantification of number of colonies per well of stable pcDNA3.1- and pSFRP1-transfected HuH-6 cells $(n=3)$. f Representative pictures and quantification of cell migration at indicated time points were normalized to zero hour time points. Slope difference was analyzed by linear regression, $* * * * p<0.0001$. g TOP/FOP reporter plasmid activity was assessed by a relative luciferase activity in stable pcDNA3.1- and pSFRP1-transfected HuH-6 cells $48 \mathrm{~h}$ after co-transfection $(n=5)$. h mRNA expression of $M Y C$ and $C C N D 1$ in stable pcDNA3.1- and pSFRP1-transfected HuH-6 cell clone 2 was determined by qRT-PCR and calculated as normalized mRNA expression (fold change) to pcDNA3.1 control $(n=4)$. i Immunofluorescence staining of $\beta$-catenin (CTNNB1, green) and DAPI nuclear staining (blue) in stable pcDNA3.1- and pSFRP1-transfected HuH-6 cells. Scale bars: $100 \mu \mathrm{m}$. All data are represented as mean \pm SEM; unless otherwise stated $p$ values were calculated by two-tailed, unpaired Student's $t$ test; $* p<0.05, * * p<0.01, * * * p<0.001$, ****p $<0.0001$

expression after 3 days (Supplementary Fig. 1a). Moreover, we analyzed if other epigenetic mechanisms, such as histone acetylation, regulate $S F R P 1$ gene expression. The 5-aza treatment of HuH-6, HepT1 and HepG2 cells alone or in combination with an HDAC inhibitor (SAHA) did not result in increased histone acetylation levels at two regulatory SFRPI genome sites, as it could be shown for EPCAM, which was included as positive control (Supplementary Fig. 1b). In conclusion, our data suggest that solely SFRP1 promoter hypermethylation is associated with a transcriptional silencing in HB tumor cell lines.

\section{Restored SFRP1 expression affects WNT signaling activity and HB tumor cell characteristics}

To study the functional relevance of $S F R P 1$ gene silencing in HB, we assessed tumor cell characteristics after SFRPI re-expression. To restore $S F R P 1$ gene expression, we transiently transfected HuH-6, HepT1 and HepG2 cells with the pcDNA3.1-SFRP1 plasmid (pSFRP1), containing fulllength SFRP1 cDNA, or with the empty vector (pcDNA3.1) as control. Expression levels of $S F R P 1$ were determined 48 and $72 \mathrm{~h}$ after transfection and showed markedly elevated
SFRP1 transcript levels (Fig. 2a, Supplementary Fig. 2a). Notably, transiently pSFRP1-transfected HuH-6, HepT1 and HepG2 cells displayed a reduced growth rate compared to control-transfected cells (Fig. 2b, Supplementary Fig. 2b). To analyze long-term effects, we generated pSFRP1 or pcDNA3.1 stably transfected HuH-6, HepT1 and HepG2 cells. For instance, the HuH- 6 cell clone 2 showed a substantial increase in SFRP1 gene and protein expression (Fig. 2c). In line with our preceding results, the stable SFRPI expression in HuH-6, HepT1 and HepG2 cells resulted in significantly impaired tumor cell growth (Fig. 2d, Supplementary Fig. 2c) and a strong decrease in colony formation (Fig. 2e, Supplementary Fig. 2d) and migration capacity (Fig. 2f) compared to control cells. To investigate whether the reexpression of $S F R P 1$ has a direct influence on the activity of the canonical WNT/ $\beta$-catenin signaling pathway, we performed a TOP/FOP luciferase reporter assay, in which the binding activity of $\beta$-catenin to the TOP reporter plasmids is measured. Strikingly, the stably pSFRP1-transfected $\mathrm{HuH}$ 6, HepT1 and HepG2 cells revealed a substantial reduction in the relative luciferase activity, indicating a suppression of the canonical WNT/ $\beta$-catenin pathway activity (Fig. $2 \mathrm{~g}$, Supplementary Fig. 2e). To corroborate these findings, we additionally measured the expression of WNT target genes and observed a significant downregulation of $M Y C$ and $C C N D 1$ in the stably pSFRP1-transfected HuH-6 cells (Fig. 2h). Interestingly, the level of $\beta$-catenin or its cellular localization is not altered in the stably pSFRP1-transfected HuH-6 cells, indicating that $S F R P 1$ re-expression abolishes the transcriptional activity of $\beta$-catenin (Fig. 2i). Altogether, our results demonstrate that a restored SFRP1 expression has tumor-suppressive effects in HB cells by reducing the activity of the canonical WNT/ $\beta$-catenin pathway.

\section{SFRP1 DNA methylation correlates with the tumor type and a late onset of the disease}

To uncover the SFRPI gene expression and DNA methylation status in primary pediatric liver tumors, we first performed a gene expression analysis on a cohort of 45 patient samples, containing $30 \mathrm{HBs}$, nine HCCs, 2 transitional liver cell tumors (TLCT) and 2 nested stromal-epithelial liver tumors (NSET) (Supplementary Table 1). Overall, we detected a low SFRP1 gene expression in $62 \%(28 / 45)$ of cases and the median $S F R P 1$ expression level was reduced in tumor tissue compared to normal liver, although the difference was not significant (Fig. 3a, b). In addition, we determined the SFRPI DNA methylation status for each case with MSP and correlated it to the SFRPI gene expression level (Fig. 3b). Notably, $43 \%$ of the patient samples with low SFRP1 expression showed SFRPI DNA methylation. Concomitantly, however, $35 \%$ of the patient samples with a high SFRP1 expression showed also SFRPI DNA 
methylation. Hence, the overall correlation between the SFRP1 DNA methylation and transcriptional status was not significant (Fig. 3b). Representative results of the MSP reactions are illustrated in Fig. 3c. To study the impact of the SFRP1 gene expression level on clinical outcome, we performed a Chi-square correlation analysis based on a low $(<1)$ and high $(>1)$ SFRP1 expression and various clinicopathological parameters (Table 1). Here, we uncovered that the SFRPI expression is significantly associated with the PRETEXT (PRE-Treatment EXTent of tumor) risk classification system (Towbin et al. 2018). Particularly, all patient samples (6/6) with the unfavorable PRETEXT category 4 displayed a low SFRP1 gene expression (Table 1). Moreover, the transcriptional level of $S F R P 1$ correlated significantly with the $\beta$-catenin $(C T N N B 1)$ mutation status. Interestingly, patient samples with mutant $B$-catenin demonstrated a reduction in $S F R P 1$ gene expression, whereas patients with wildtype ß-catenin revealed increased SFRP1 expression levels (Fig. 3d). Since 18 out of 45 patient samples exhibited SFRPI DNA methylation, we performed also a Chi-square correlation analysis based on a methylated (M) and unmethylated (U) SFRP1 profile (Table 2). The SFRP1 methylation status was significantly associated with the gender, age at diagnosis, tumor type, differentiation, extrahepatic growth, resection margin and telomerase reverse transcriptase (TERT) mutations (Table 2). The distribution of SFRP1-methylated and -unmethylated cases in relation to the tumor type clearly showed that most of the HCC/TLCT a

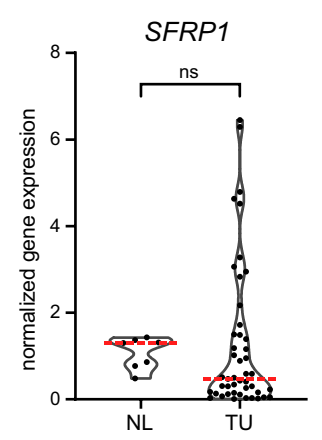

b

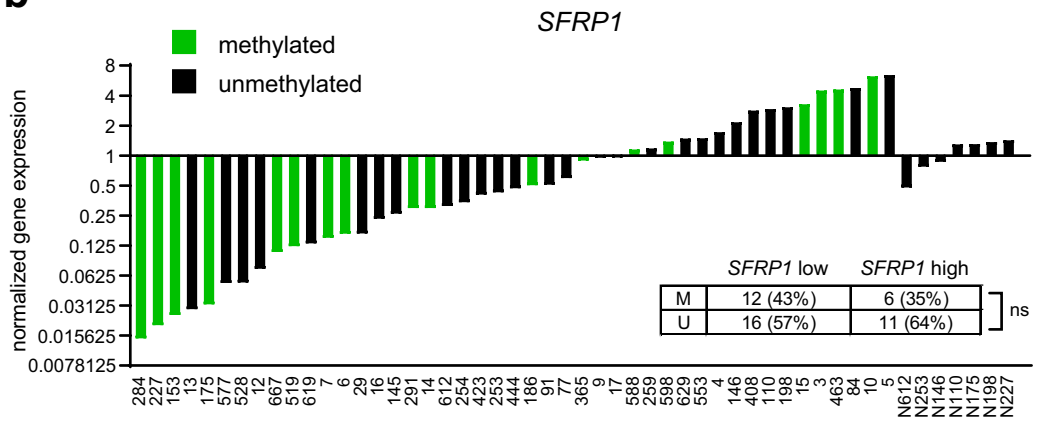

C

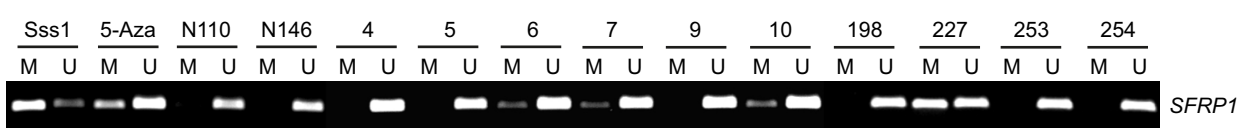

d

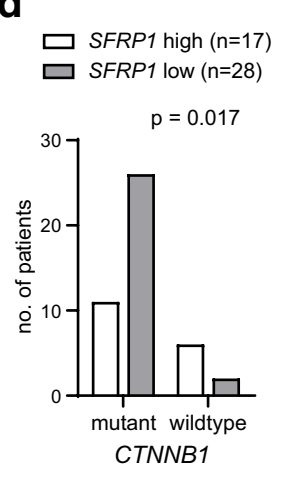

e

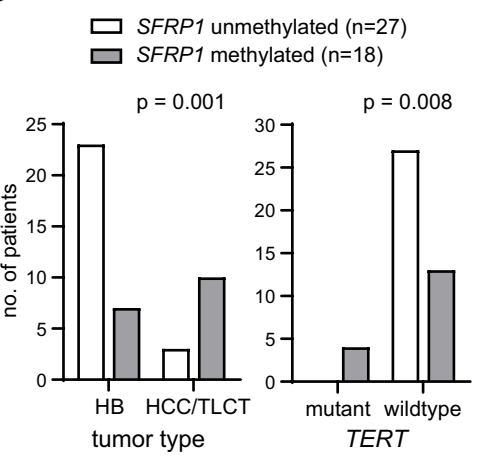

$\mathbf{f}$

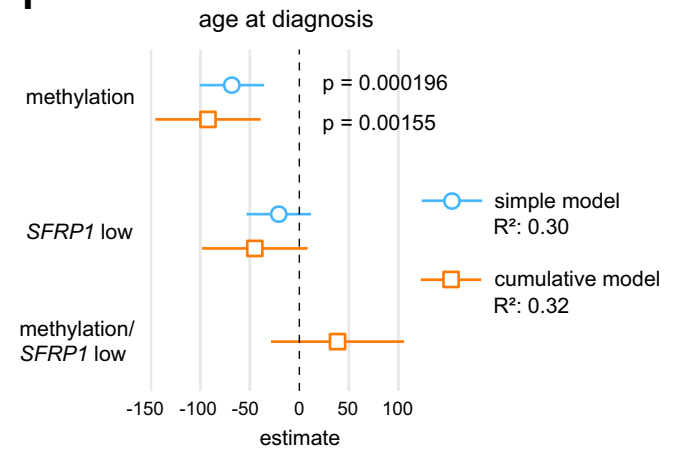

Fig. 3 SFRP1 DNA methylation correlates with the tumor type and late onset of the disease. a mRNA expression of SFRP1 in normal liver (NL) and patient tumor samples (TU) was determined by qRTPCR and calculated as normalized mRNA expression (fold change) to NL controls. The red line marks the median expression level. b For each tumor and normal tissue ( $N$-number) sample, the normalized SFRP1 gene expression and promoter methylation status is shown. The embedded table displays the distribution of methylated (M) and unmethylated (U) SFRP1 in the SFRP1 low and high gene expression categories. c Representative pictures of the SFRP1
MSP reaction from selected normal and tumor tissue samples. Sss1treated DNA serves as methylated positive control, 5-aza-treated DNA as unmethylated control. d Illustration of the correlation analysis of SFRP1 gene expression and $\beta$-catenin mutation status, see also Table 1. e Illustration of the correlation analysis of SFRP1 DNA methylation status to the tumor type, considering only $\mathrm{HB}$ and $\mathrm{HCC} /$ TLCT tumors, and to the TERT mutation status, see also Table 2. $\mathbf{f}$ Forest plot with a simple and cumulative generalized linear regression model considering SFRP1 methylation status, gene expression category and a combined profile in respect to the age at diagnosis 
Table 1 Correlation analysis of SFRP1 gene expression

\begin{tabular}{|c|c|c|c|c|}
\hline SFRP1 expression & High $(n=17)$ & Low $(n=28)$ & Total $(n=45)$ & $p$ value \\
\hline Gender & & & & 0.848 \\
\hline $\mathrm{f}$ & $8(47.1 \%)$ & $14(50.0 \%)$ & $22(48.9 \%)$ & \\
\hline $\mathrm{m}$ & $9(52.9 \%)$ & $14(50.0 \%)$ & $23(51.1 \%)$ & \\
\hline Age at diagnosis in month & & & & 0.386 \\
\hline nd & 0 & 1 & 1 & \\
\hline Mean (SD) & $67.867(72.955)$ & $50.780(55.905)$ & $57.382(62.777)$ & \\
\hline Range & $1.874-199.435$ & $0.000-184.179$ & $0.000-199.435$ & \\
\hline Outcome & & & & 0.758 \\
\hline DOD & $3(17.6 \%)$ & $6(21.4 \%)$ & $9(20.0 \%)$ & \\
\hline NED & $14(82.4 \%)$ & $22(78.6 \%)$ & $36(80.0 \%)$ & \\
\hline Cause of death & & & & 0.541 \\
\hline nd & 0 & 1 & 1 & \\
\hline Progressive & $2(11.8 \%)$ & $2(7.4 \%)$ & $4(9.1 \%)$ & \\
\hline Recurrence & $2(11.8 \%)$ & $3(11.1 \%)$ & $5(11.1 \%)$ & \\
\hline Alive & $13(76.5 \%)$ & $22(81.5 \%)$ & $35(79.5 \%)$ & \\
\hline Tumor type & & & & 0.170 \\
\hline $\mathrm{HB}$ & $10(58.8 \%)$ & $20(71.4 \%)$ & $30(66.7 \%)$ & \\
\hline HCC/TLCT & $5(29.4 \%)$ & $8(28.6 \%)$ & $13(28.9 \%)$ & \\
\hline NSET & $2(11.8 \%)$ & $0(0.0 \%)$ & $2(4.4 \%)$ & \\
\hline Differentiation & & & & 0.388 \\
\hline nd & 2 & 0 & 2 & \\
\hline Epithelial & $6(40.0 \%)$ & $17(60.7 \%)$ & $23(53.5 \%)$ & \\
\hline Fibrolamellar & $3(20.0 \%)$ & $1(3.6 \%)$ & $4(9.3 \%)$ & \\
\hline Well differentiated & $0(0.0 \%)$ & $2(7.1 \%)$ & $2(4.4 \%)$ & \\
\hline Moderately differentiated & $1(6.7 \%)$ & $2(7.1 \%)$ & $3(7.0 \%)$ & \\
\hline Mixed & $5(33.3 \%)$ & $6(21.4 \%)$ & $11(25.6 \%)$ & \\
\hline Component & & & & 0.332 \\
\hline na & $6(35.3 \%)$ & $5(17.9 \%)$ & $11(24.4 \%)$ & \\
\hline $\mathrm{E}$ & $1(5.9 \%)$ & $0(0.0 \%)$ & $1(2.2 \%)$ & \\
\hline $\mathrm{E} / \mathrm{F}$ & $3(17.6 \%)$ & $6(21.4 \%)$ & $9(20.0 \%)$ & \\
\hline $\mathrm{E}>\mathrm{F}$ & $1(5.9 \%)$ & $1(3.6 \%)$ & $2(4.4 \%)$ & \\
\hline $\mathrm{F}$ & $2(11.8 \%)$ & $4(14.3 \%)$ & $6(13.3 \%)$ & \\
\hline $\mathrm{F}>\mathrm{E}$ & $3(17.6 \%)$ & $12(42.9 \%)$ & $15(33.3 \%)$ & \\
\hline Pure OS & $1(5.9 \%)$ & $0(0.0 \%)$ & $1(2.2 \%)$ & \\
\hline Stage & & & & 0.296 \\
\hline nd & 2 & 1 & 3 & \\
\hline I & $1(6.7 \%)$ & $6(22.2 \%)$ & $7(16.7 \%)$ & \\
\hline II & $0(0.0 \%)$ & $1(3.7 \%)$ & $1(2.4 \%)$ & \\
\hline III & $9(60.0 \%)$ & $9(33.3 \%)$ & $18(42.9 \%)$ & \\
\hline IV & $5(33.3 \%)$ & $11(40.7 \%)$ & $16(38.1 \%)$ & \\
\hline PRETEXT & & & & 0.025 \\
\hline nd & 3 & 1 & 4 & \\
\hline 1 & $2(13.3 \%)$ & $0(0.0 \%)$ & $2(4.8 \%)$ & \\
\hline 2 & $3(20.0 \%)$ & $11(40.7 \%)$ & $14(33.3 \%)$ & \\
\hline 3 & $9(60.0 \%)$ & $10(37.0 \%)$ & $19(45.2 \%)$ & \\
\hline 4 & $0(0.0 \%)$ & $6(22.2 \%)$ & $6(14.3 \%)$ & \\
\hline Extrahepatic & & & & 0.820 \\
\hline nd & 0 & 2 & 2 & \\
\hline No & $16(94.1 \%)$ & $24(92.3 \%)$ & $40(93.0 \%)$ & \\
\hline Yes & $1(5.9 \%)$ & $2(7.7 \%)$ & $3(7.0 \%)$ & \\
\hline Multifocal & & & & 0.666 \\
\hline
\end{tabular}


Table 1 (continued)

\begin{tabular}{|c|c|c|c|c|}
\hline$S F R P 1$ expression & High $(n=17)$ & Low $(n=28)$ & Total $(n=45)$ & $p$ value \\
\hline nd & 2 & 1 & 3 & \\
\hline No & $12(80.0 \%)$ & $20(74.1 \%)$ & $32(76.2 \%)$ & \\
\hline Yes & $3(20.0 \%)$ & $7(25.9 \%)$ & $10(23.8 \%)$ & \\
\hline Metastasis & & & & 0.447 \\
\hline nd & 0 & 1 & 1 & \\
\hline No & $12(70.6 \%)$ & $16(59.3 \%)$ & $28(63.6 \%)$ & \\
\hline Yes & $5(29.4 \%)$ & $11(40.7 \%)$ & $16(36.4 \%)$ & \\
\hline Chemotherapy & & & & 0.282 \\
\hline No & $2(11.8 \%)$ & $7(25.0 \%)$ & $9(20.0 \%)$ & \\
\hline Yes & $15(88.2 \%)$ & $21(75.0 \%)$ & $36(80.0 \%)$ & \\
\hline Resection margin & & & & 0.911 \\
\hline $\mathrm{Nd}$ & 2 & 1 & 3 & \\
\hline R0 & $13(81.2 \%)$ & $23(82.1 \%)$ & $36(81.8 \%)$ & \\
\hline $\mathrm{R} 1$ & $2(12.5 \%)$ & $4(14.3 \%)$ & $6(13.6 \%)$ & \\
\hline 16-gene signature & & & & 0.172 \\
\hline na & $2(11.8 \%)$ & $0(0.0 \%)$ & $2(4.4 \%)$ & \\
\hline $\mathrm{C} 1$ & $9(52.9 \%)$ & $18(64.3 \%)$ & $27(60.0 \%)$ & \\
\hline $\mathrm{C} 2$ & $6(35.3 \%)$ & $10(35.7 \%)$ & $16(35.6 \%)$ & \\
\hline CTNNB1 & & & & 0.017 \\
\hline Mutant & $11(64.7 \%)$ & $26(92.9 \%)$ & $37(82.2 \%)$ & \\
\hline Wildtype & $6(35.3 \%)$ & $2(7.1 \%)$ & $8(17.8 \%)$ & \\
\hline NFE2L2 & & & & 0.137 \\
\hline nd & 3 & 0 & 3 & \\
\hline Mutant & $0(0.0 \%)$ & $4(14.3 \%)$ & $4(9.5 \%)$ & \\
\hline Wildtype & $14(100.0 \%)$ & $24(85.7 \%)$ & $38(90.5 \%)$ & \\
\hline TERT & & & & 0.620 \\
\hline nd & 1 & 0 & 1 & \\
\hline Mutant & $1(6.2 \%)$ & $3(10.7 \%)$ & $4(9.1 \%)$ & \\
\hline Wildtype & $15(93.8 \%)$ & $25(89.3 \%)$ & $40(90.9 \%)$ & \\
\hline SFRP1 methylation & & & & 0.616 \\
\hline M & $6(35.3 \%)$ & $12(42.9 \%)$ & $18(40.0 \%)$ & \\
\hline $\mathrm{U}$ & $11(64.7 \%)$ & $16(57.1 \%)$ & $27(60.0 \%)$ & \\
\hline
\end{tabular}

Chi-square correlation analysis of normalized low $(<1)$ and high $(>1)$ SFRP1 expression categories to different clinicopathological and experimental parameters

$m$ male, $f$ female, $D O D$ died of disease, $N E D$ no evidence of disease, $H B$ hepatoblastoma, $H C C$ hepatocellular carcinoma, TLCT transitional liver cell tumor, NSET nested stromal-epithelial liver tumor, $E$ embryonal, $F$ fetal, pure $O S$ pure osteoid, $C 1$ and $C 2$ 16-gene signature cluster C1 and C2 (Cairo et al. 2008), $M$ methylated, $U$ unmethylated, $n d$ no data, $n a$ not applicable

samples displayed an enrichment of SFRPI DNA methylation and that all tumors with a TERT mutation were SFRPImethylated (Fig. 3e). Of further note, SFRPI DNA methylation as a single parameter was significantly associated with an older age at diagnosis, although a low SFRP1 expression did not correlate with the age in a simple or cumulative correlation model (Fig. 3f). Overall, our findings revealed that SFRPI DNA methylation and transcriptional silencing is a common event in pediatric liver cancer and that SFRPI DNA methylation is a preferential characteristic of pediatric liver tumors with HCC-like features, such as hepatocellular histology, advanced age and TERT mutations.

\section{Discussion}

A constitutive activation of the WNT/ $\beta$-catenin signaling pathway is a common event in pediatric liver tumor development. During embryogenesis, the pathway controls liver development and hepatoblast proliferation, indicating that a signaling malfunction contributes to liver cell transformation and tumor development (Perugorria et al. 2019). Indeed, HBs and HCCs exhibit an increased mutational burden in WNT/ $\beta$-catenin pathway components that affect $C T N N B 1$, $A P C, A X I N 1$ and AXIN2 genes (Tate et al. 2019). Although most of the mutations promote stabilization of $\beta$-catenin and 
Table 2 Correlation analysis of $S F R P 1$ promoter methylation

\begin{tabular}{|c|c|c|c|c|}
\hline SFRP1 methylation & $\mathrm{M}(n=18)$ & $\mathrm{U}(n=27)$ & Total $(n=45)$ & $p$ value \\
\hline Gender & & & & 0.021 \\
\hline $\mathrm{f}$ & $5(27.8 \%)$ & $17(63.0 \%)$ & $22(48.9 \%)$ & \\
\hline $\mathrm{m}$ & $13(72.2 \%)$ & $10(37.0 \%)$ & $23(51.1 \%)$ & \\
\hline Age at diagnosis in month & & & & $<0.001$ \\
\hline nd & 1 & 0 & 1 & \\
\hline Mean (SD) & $98.48(73.09)$ & $31.50(37.82)$ & $57.38(62.78)$ & \\
\hline Range & $7.37-199.44$ & $0.00-156.33$ & $0.00-199.44$ & \\
\hline Outcome & & & & 0.287 \\
\hline DOD & $5(27.8 \%)$ & $4(14.8 \%)$ & $9(20.0 \%)$ & \\
\hline NED & $13(72.2 \%)$ & $23(85.2 \%)$ & $36(80.0 \%)$ & \\
\hline Cause of death & & & & 0.512 \\
\hline nd & 1 & 0 & 1 & \\
\hline Progressive & $2(11.8 \%)$ & $2(7.4 \%)$ & $4(9.1 \%)$ & \\
\hline Recurrence & $3(16.6 \%)$ & $2(7.4 \%)$ & $5(11.1 \%)$ & \\
\hline Alive & $12(70.6 \%)$ & $23(85.2 \%)$ & $35(79.5 \%)$ & \\
\hline Tumor type & & & & 0.004 \\
\hline HB & $7(38.9 \%)$ & $23(85.2 \%)$ & $30(66.7 \%)$ & \\
\hline HCC/TLCT & $10(55.6 \%)$ & $3(11.1 \%)$ & $13(28.9 \%)$ & \\
\hline NSET & $1(5.6 \%)$ & $1(3.7 \%)$ & $2(4.4 \%)$ & \\
\hline Differentiation & & & & 0.042 \\
\hline nd & 1 & 1 & 2 & \\
\hline Epithelial & $8(47.1 \%)$ & $15(57.7 \%)$ & $23(53.5 \%)$ & \\
\hline Fibrolamellar & $4(23.5 \%)$ & $0(0.0 \%)$ & $4(9.3 \%)$ & \\
\hline Well differentiated & $1(5.9 \%)$ & $1(3.8 \%)$ & $2(4.4 \%)$ & \\
\hline Moderately differentiated & $2(11.8 \%)$ & $1(3.8 \%)$ & $3(7.0 \%)$ & \\
\hline Mixed & $2(11.8 \%)$ & $9(34.6 \%)$ & $11(25.6 \%)$ & \\
\hline Component & & & & 0.260 \\
\hline na & $8(44.4 \%)$ & $3(11.1 \%)$ & $11(24.4 \%)$ & \\
\hline $\mathrm{E}$ & $0(0.0 \%)$ & $1(3.7 \%)$ & $1(2.2 \%)$ & \\
\hline $\mathrm{E} / \mathrm{F}$ & $3(16.7 \%)$ & $6(22.2 \%)$ & $9(20.0 \%)$ & \\
\hline $\mathrm{E}>\mathrm{F}$ & $1(5.6 \%)$ & $1(3.7 \%)$ & $2(4.4 \%)$ & \\
\hline $\mathrm{F}$ & $2(11.1 \%)$ & $4(14.8 \%)$ & $6(13.3 \%)$ & \\
\hline $\mathrm{F}>\mathrm{E}$ & $4(22.2 \%)$ & $11(40.7 \%)$ & $15(33.3 \%)$ & \\
\hline pure OS & $0(0.0 \%)$ & $1(3.7 \%)$ & $1(2.2 \%)$ & \\
\hline Stage & & & & 0.078 \\
\hline nd & 1 & 2 & 3 & \\
\hline I & $5(29.4 \%)$ & $2(8.0 \%)$ & $7(16.7 \%)$ & \\
\hline II & $1(5.9 \%)$ & $0(0.0 \%)$ & $1(2.4 \%)$ & \\
\hline III & $4(23.5 \%)$ & $14(56.0 \%)$ & $18(42.9 \%)$ & \\
\hline IV & $7(41.2 \%)$ & $9(36.0 \%)$ & $16(38.1 \%)$ & \\
\hline PRETEXT & & & & 0.552 \\
\hline nd & 4 & 0 & 4 & \\
\hline 1 & $1(6.7 \%)$ & $1(3.7 \%)$ & $2(4.8 \%)$ & \\
\hline 2 & $6(40.0 \%)$ & $8(29.6 \%)$ & $14(33.3 \%)$ & \\
\hline 3 & $5(33.3 \%)$ & $14(51.9 \%)$ & $19(45.2 \%)$ & \\
\hline 4 & $2(13.3 \%)$ & $4(14.8 \%)$ & $6(14.3 \%)$ & \\
\hline Extrahepatic & & & & 0.020 \\
\hline nd & 2 & 0 & 2 & \\
\hline No & $13(81.2 \%)$ & $27(100.0 \%)$ & $40(93.0 \%)$ & \\
\hline Yes & $3(18.8 \%)$ & $0(0.0 \%)$ & $3(7.0 \%)$ & \\
\hline Multifocal & & & & 0.280 \\
\hline
\end{tabular}


Table 2 (continued)

\begin{tabular}{|c|c|c|c|c|}
\hline SFRP1 methylation & $\mathrm{M}(n=18)$ & $\mathrm{U}(n=27)$ & Total $(n=45)$ & $p$ value \\
\hline nd & 3 & 0 & 3 & \\
\hline No & $10(66.7 \%)$ & $22(81.5 \%)$ & $32(76.2 \%)$ & \\
\hline Yes & $5(33.3 \%)$ & $5(18.5 \%)$ & $10(23.8 \%)$ & \\
\hline Metastasis & & & & 0.598 \\
\hline nd & 1 & 0 & 1 & \\
\hline No & $10(58.8 \%)$ & $18(66.7 \%)$ & $28(63.6 \%)$ & \\
\hline Yes & $7(41.2 \%)$ & $9(33.3 \%)$ & $16(36.4 \%)$ & \\
\hline Chemotherapy & & & & 0.761 \\
\hline No & $4(22.2 \%)$ & $5(18.5 \%)$ & $9(20.0 \%)$ & \\
\hline Yes & $14(77.8 \%)$ & $22(81.5 \%)$ & $36(80.0 \%)$ & \\
\hline Resection margin & & & & 0.046 \\
\hline nd & 3 & 0 & 3 & \\
\hline R0 & $11(64.7 \%)$ & $25(92.6 \%)$ & $36(81.8 \%)$ & \\
\hline $\mathrm{R} 1$ & $4(23.5 \%)$ & $2(7.4 \%)$ & $6(13.6 \%)$ & \\
\hline 16-gene signature & & & & 0.871 \\
\hline na & $1(5.6 \%)$ & $1(3.7 \%)$ & $2(4.4 \%)$ & \\
\hline $\mathrm{C} 1$ & $10(55.6 \%)$ & $17(63.0 \%)$ & $27(60.0 \%)$ & \\
\hline $\mathrm{C} 2$ & $7(38.9 \%)$ & $9(33.3 \%)$ & $16(35.6 \%)$ & \\
\hline CTNNB1 & & & & 0.340 \\
\hline Mutant & $16(88.9 \%)$ & $21(77.8 \%)$ & $37(82.2 \%)$ & \\
\hline Wildtype & $2(11.1 \%)$ & $6(22.2 \%)$ & $8(17.8 \%)$ & \\
\hline NFE2L2 & & & & 0.571 \\
\hline nd & 2 & 1 & 3 & \\
\hline Mutant & $1(6.2 \%)$ & $3(11.5 \%)$ & $4(9.5 \%)$ & \\
\hline Wildtype & $15(93.8 \%)$ & $23(88.5 \%)$ & $38(90.5 \%)$ & \\
\hline TERT & & & & 0.008 \\
\hline nd & 1 & 0 & 1 & \\
\hline Mutant & $4(23.5 \%)$ & $0(0.0 \%)$ & $4(9.1 \%)$ & \\
\hline Wildtype & $13(76.5 \%)$ & $27(100.0 \%)$ & $40(90.9 \%)$ & \\
\hline$S F R P 1$ expression & & & & 0.908 \\
\hline Mean (SD) & 1.327 (1.956) & $1.265(1.575)$ & $1.290(1.716)$ & \\
\hline Range & $0.015-6.287$ & $0.029-6.450$ & $0.015-6.450$ & \\
\hline SFRPI exp. category & & & & 0.616 \\
\hline High & $6(33.3 \%)$ & $11(40.7 \%)$ & $17(37.8 \%)$ & \\
\hline Low & $12(66.7 \%)$ & $16(59.3 \%)$ & $28(62.2 \%)$ & \\
\hline
\end{tabular}

Chi-square correlation analysis of methylated (M) and unmethylated (U) SFRP1 categories to different clinicopathological and experimental parameters

$m$ male, $f$ female, $D O D$ died of disease, $N E D$ no evidence of disease, $H B$ hepatoblastoma, $H C C$ hepatocellular carcinoma, TLCT transitional liver cell tumor, NSET nested stromal-epithelial liver tumor, $E$ embryonal, $F$ fetal, pure $O S$ pure osteoid, $C 1$ and C2 16-gene signature cluster C1 and C2 (Cairo et al. 2008), nd no data, $n a$ not applicable

pathway hyperactivation, several studies have reported that an additional epigenetic inhibition of WNT antagonists is important for cancer formation (Anastas and Moon 2013; Suzuki et al. 2008). In different tumor entities, an epigenetic silencing of various WNT antagonist, such as WIFs, DKKs and SFRPs, correlates with a poor prognosis or high-grade cancer (Kardum et al. 2017; Lin et al. 2017; Davaadorj et al. 2016). Interestingly, a restoration of the WNT antagonist expression attenuated tumor growth (Shih et al. 2007; Gumz et al. 2007). In the present study, we addressed the role of the WNT inhibitory factor SFRPl in HB and pediatric HCC, since its functional relevance has not been specified, yet. By determining the endogenous gene expression and DNA methylation status of the WNT antagonists $A P C, D K K 1$, SFRPI and WIFI in four HB cell lines, we detected a heterogeneous pattern. Although all four genes were methylated in $\mathrm{HB}$ cells, with the exception of $D K K 1$ in HuH-6 cells, only $A P C$ and $S F R P 1$ revealed a concomitant transcriptional 
repression. Moreover, a treatment of the tumor cells with 5-aza solely restored SFRP1 expression in all four cell lines, indicating that DNA methylation is responsible for the SFRPI suppression in HB cell lines. We detected no involvement of histone acetylation on $S F R P 1$ regulatory gene sites. Nevertheless, besides DNA methylation, histone modifications might control the expression of other WNT antagonist. Based on these results, we focused our functional analyses on SFRPI and overexpressed the gene in the HB cell lines HuH6, HepT1 and HepG2. In line with studies in HCC and other tumor entities, a re-expression of SFRPI inhibited tumor cell growth, colony formation and migration of HB tumor cells (Shih et al. 2007; Kaur et al. 2012; Wang et al. 2018). In contrast to Shih et al. (2007), our data demonstrated that cell lines which possess $\beta$-catenin deletion mutations, such as HepT1 and HepG2 cells, also exhibited canonical WNT inhibition. Interestingly, SFRPI re-expression diminished the canonical $\mathrm{WNT} / \beta$-catenin signaling activity and we detected a downregulation of the WNT target genes $M Y C$ and $C C N D 1$, although the HB cell lines carry beta-catenin mutations. Moreover, we uncovered that the overall level and cellular localization of $\beta$-catenin is not changed after restored SFRP1 expression. Based on these results, we suppose that $S F R P 1$ expression abolishes $\beta$-catenin-driven transcription activity. In accordance, it was shown that the SFRP1-mediated inhibition of the WNT pathway was independent from wildtype or mutant $\beta$-catenin in colorectal cancer cells (Suzuki et al. 2004). Hence, the epigenetic silencing of the Wnt antagonists SFRP1 is an important mechanism in pediatric liver carcinogenesis, promoting WNT signaling-mediated oncogenic transformation.

Notably, in our pediatric liver cancer cohort, we detected a reduced SFRPI gene expression in around 62\% (28/45) of cases. To our knowledge, we show for the first time that low SFRP1 expression correlated significantly with a worse classification in the PRETEXT stratification system and to $\beta$-catenin mutations, indicating that $S F R P 1$ gene silencing in $\beta$-catenin mutant cancer leads to a more aggressive cancer growth. SFRP1 repression might potentiate the oncogenic function of the WNT signaling pathway, particularly in $\beta$-catenin mutant cancers. Thus, a restoration of the SFRP1 expression through epigenetic drugs or the natural compound flavonoid epigallocatechin-3-gallate (EGCG), as it was shown in our recent study, could be a new therapeutic option for $\beta$-catenin mutant pediatric liver cancers (Godeke et al. 2013). In contrast to other studies, the reduced SFRPI gene expression in our HB patient cohort was not associated to the DNA methylation status (Vincent and Postovit 2017; Kaur et al. 2012). Several patient samples showed a SFRP1 downregulation without a concomitant methylation of the promoter. With the help of the MSP, we determined the methylation status of only a few cytosines in the $\mathrm{CpG}$ island, thus we cannot exclude the possibility that adjacent cytosines might be methylated, which would result in gene silencing (Hernandez et al. 2013). Moreover, recent studies proposed a microRNA-dependent inhibition of SFRP1 in different cancer entities, which may also occur in pediatric liver cancer (Ba et al. 2017; Li et al. 2017). Overall, we identified promoter methylation of SFRPI in $40 \%$ (18/45) of the analyzed cases. Importantly, the SFRPI methylation correlated with HCC-like pediatric liver tumors, with a higher age at diagnosis and with TERT mutations. It needs to be taken into consideration that these clinical features are dependent on each other, since the tumor manifests at older ages in the HCC/TLCT group (Tomlinson and Kappler 2012), which is furthermore characterized by frequent TERT mutations (Eichenmuller et al. 2014). Although in several tumor entities, SFRP1 expression or methylation was proposed as a prognostic biomarker (Davaadorj et al. 2016; Zheng et al. 2015; Atschekzei et al. 2012), this was not the case for our cohort of pediatric liver cancers.

\section{Conclusion}

In conclusion, we delineated an important role for the epigenetic silencing of SFRPI in pediatric liver cancer cell lines and patient samples. Our data demonstrated that $\beta$-catenin mutant pediatric liver cancers are accompanied by a suppression of the WNT antagonist SFRP1, which promotes malignant tumor cell characteristics. SFRP1 methylation was highly associated to advanced pediatric liver tumors, with HCC-like features and TERT mutations. However, further studies are needed to clarify whether SFRPl gene expression or methylation could serve as a potential prognostic or diagnostic biomarker for HB or pediatric HCC.

Acknowledgements Open Access funding provided by Projekt DEAL. We thank Maria del Socorro Escobar Lopez, Nicole Stadler, Fatemeh Promoli for technical assistance. We thank Dr. Takayuki Fukui (University of Nagoya, Japan) for kindly providing the pSFRP1 expression vector and Dr. Torsten Pietsch (University of Bonn, Germany) for the HepT1 and Hep-T3 cell lines.

Authors' contributions IR and RK designed the study. IR, ME and SB developed methodology. IR, ME, BHag, performed experiments and collected data. IR, ME, UMM and RK extracted and analyzed data. BH, DS and RK collected patient samples and data. CV evaluated tissue histology of patient samples. SB, BH, DS and RK gave administrative, technical, or material support. IR, ME, SB and RK wrote the manuscript. All authors read and approved the final manuscript.

Funding This work was supported by grants of the Deutsche Forschungsgemeinschaft (KA2274/3-1), the Bettina Bräu foundation, Munich, and the Gänseblümchen foundation, Voerde (to R.K.). 


\section{Compliance with ethical standards}

Conflict of interest The authors declare that they have no conflict of interests.

Availability of data and materials All data generated or analyzed during this study are included in this published article and its supplementary information files.

\section{Consent for publication Not applicable.}

Ethics approval and consent to participate Each patient gave written informed consent and the study protocol was approved by the Committee of Ethics, LMU Munich, Germany.

Open Access This article is licensed under a Creative Commons Attribution 4.0 International License, which permits use, sharing, adaptation, distribution and reproduction in any medium or format, as long as you give appropriate credit to the original author(s) and the source, provide a link to the Creative Commons licence, and indicate if changes were made. The images or other third party material in this article are included in the article's Creative Commons licence, unless indicated otherwise in a credit line to the material. If material is not included in the article's Creative Commons licence and your intended use is not permitted by statutory regulation or exceeds the permitted use, you will need to obtain permission directly from the copyright holder. To view a copy of this licence, visit http://creativecommons.org/licenses/by/4.0/.

\section{References}

Aguilera O, Fraga MF, Ballestar E, Paz MF, Herranz M, Espada J et al (2006) Epigenetic inactivation of the Wnt antagonist DICKKOPF-1 (DKK-1) gene in human colorectal cancer. Oncogene 25(29):4116-4121

Anastas JN, Moon RT (2013) WNT signalling pathways as therapeutic targets in cancer. Nat Rev Cancer 13(1):11-26

Atschekzei F, Hennenlotter J, Janisch S, Grosshennig A, Trankenschuh W, Waalkes S et al (2012) SFRP1 CpG Island methylation locus is associated with renal cell cancer susceptibility and disease recurrence. Epigenetics 7(5):447-457

Ba S, Xuan Y, Long ZW, Chen HY, Zheng SS (2017) MicroRNA-27a promotes the proliferation and invasiveness of colon cancer cells by targeting SFRP1 through the $\mathrm{Wnt} / \beta$-catenin signaling pathway. Cell Physiol Biochem 42(5):1920-1933

Bell D, Ranganathan S, Tao J, Monga SP (2017) Novel Advances in understanding of molecular pathogenesis of hepatoblastoma: a Wnt/ $\beta$-catenin perspective. Gene Exp 17(2):141-154

Benitz S, Straub T, Mahajan UM, Mutter J, Czemmel S, Unruh T et al (2019) Ring1b-dependent epigenetic remodelling is an essential prerequisite for pancreatic carcinogenesis. Gut 68(11):2007-2018

Cairo S, Armengol C, De Reynies A, Wei Y, Thomas E, Renard CA et al (2008) Hepatic stem-like phenotype and interplay of Wnt/ beta-catenin and Myc signaling in aggressive childhood liver cancer. Cancer Cell 14(6):471-484

Czauderna P, Garnier H (2018) Hepatoblastoma: current understanding, recent advances, and controversies. F1000Res 7:53

Czauderna P, Haeberle B, Hiyama E, Rangaswami A, Krailo M, Maibach R et al (2016) The Children's Hepatic tumors International Collaboration (CHIC): novel global rare tumor database yields new prognostic factors in hepatoblastoma and becomes a research model. Eur J Cancer 52:92-101
Davaadorj M, Imura S, Saito YU, Morine Y, Ikemoto T, Yamada S et al (2016) Loss of SFRP1 expression is associated with poor prognosis in hepatocellular carcinoma. Anticancer Res 36(2):659-664

Eichenmuller M, Gruner I, Hagl B, Haberle B, Muller-Hocker J, von Schweinitz D et al (2009) Blocking the hedgehog pathway inhibits hepatoblastoma growth. Hepatology 49(2):482-490

Eichenmuller M, Trippel F, Kreuder M, Beck A, Schwarzmayr T, Haberle B et al (2014) The genomic landscape of hepatoblastoma and their progenies with HCC-like features. J Hepatol 61(6):1312-1320

Esteller M, Sparks A, Toyota M, Sanchez-Cespedes M, Capella G, Peinado MA et al (2000) Analysis of adenomatous polyposis coli promoter hypermethylation in human cancer. Cancer Res 60(16):4366-4371

Fukui T, Kondo M, Ito G, Maeda O, Sato N, Yoshioka H et al (2005) Transcriptional silencing of secreted frizzled related protein 1 (SFRP 1) by promoter hypermethylation in non-small-cell lung cancer. Oncogene 24(41):6323-6327

Godeke J, Maier S, Eichenmuller M, Muller-Hocker J, von Schweinitz D, Kappler R (2013) Epigallocatechin-3-gallate inhibits hepatoblastoma growth by reactivating the Wnt inhibitor SFRP1. Nutr Cancer 65(8):1200-1207

Gumz ML, Zou H, Kreinest PA, Childs AC, Belmonte LS, LeGrand SN et al (2007) Secreted frizzled-related protein 1 loss contributes to tumor phenotype of clear cell renal cell carcinoma. Clin Cancer Res 13(16):4740-4749

Hernandez HG, Tse MY, Pang SC, Arboleda H, Forero DA (2013) Optimizing methodologies for PCR-based DNA methylation analysis. Biotechniques 55(4):181-197

Huang J, Zhang YL, Teng XM, Lin Y, Zheng DL, Yang PY et al (2007) Down-regulation of SFRP1 as a putative tumor suppressor gene can contribute to human hepatocellular carcinoma. BMC Cancer 7:126

Kardum V, Karin V, Glibo M, Skrtic A, Martic TN, Ibisevic N et al (2017) Methylation-associated silencing of SFRP1 gene in highgrade serous ovarian carcinomas. Ann Diagn Pathol 31:45-49

Kaur P, Mani S, Cros MP, Scoazec JY, Chemin I, Hainaut P et al (2012) Epigenetic silencing of sFRP1 activates the canonical Wnt pathway and contributes to increased cell growth and proliferation in hepatocellular carcinoma. Tumour Biol 33(2):325-336

Kawano Y, Kypta R (2003) Secreted antagonists of the Wnt signalling pathway. J Cell Sci 116(Pt 13):2627-2634

Khanna R, Verma SK (2018) Pediatric hepatocellular carcinoma. World J Gastroenterol 24(35):3980-3999

Kremer N, Walther AE, Tiao GM (2014) Management of hepatoblastoma: an update. Curr Opin Pediatr 26(3):362-369

Li H, Yang T, Shang D, Sun Z (2017) miR-1254 promotes lung cancer cell proliferation by targeting SFRP1. Biomed Pharmacother 92:913-918

Lin B, Hong H, Jiang X, Li C, Zhu S, Tang N et al (2017) WNT inhibitory factor 1 promoter hypermethylation is an early event during gallbladder cancer tumorigenesis that predicts poor survival. Gene 622:42-49

Lo PK, Mehrotra J, D'Costa A, Fackler MJ, Garrett-Mayer E, Argani $P$ et al (2006) Epigenetic suppression of secreted frizzled related protein 1 (SFRP1) expression in human breast cancer. Cancer Biol Ther 5(3):281-286

Lodygin D, Epanchintsev A, Menssen A, Diebold J, Hermeking H (2005) Functional epigenomics identifies genes frequently silenced in prostate cancer. Cancer Res 65(10):4218-4227

Ng K, Mogul DB (2018) Pediatric liver tumors. Clin Liver Dis 22(4):753-772

Perugorria MJ, Olaizola P, Labiano I, Esparza-Baquer A, Marzioni M, Marin JJG et al (2019) Wnt-beta-catenin signalling in liver 
development, health and disease. Nat Rev Gastroenterol Hepatol 16(2):121-136

Russell JO, Monga SP (2018) Wnt/ $\beta$-catenin signaling in liver development, homeostasis, and pathobiology. Annu Rev Pathol 13:351-378

Shih YL, Shyu RY, Hsieh CB, Lai HC, Liu KY, Chu TY et al (2006) Promoter methylation of the secreted frizzled-related protein 1 gene SFRP1 is frequent in hepatocellular carcinoma. Cancer 107(3):579-590

Shih YL, Hsieh CB, Lai HC, Yan MD, Hsieh TY, Chao YC et al (2007) SFRP1 suppressed hepatoma cells growth through Wnt canonical signaling pathway. Int J Cancer 121(5):1028-1035

Suzuki H, Watkins DN, Jair KW, Schuebel KE, Markowitz SD, Chen WD et al (2004) Epigenetic inactivation of SFRP genes allows constitutive WNT signaling in colorectal cancer. Nat Genet 36(4):417-422

Suzuki H, Toyota M, Carraway H, Gabrielson E, Ohmura T, Fujikane $\mathrm{T}$ et al (2008) Frequent epigenetic inactivation of Wnt antagonist genes in breast cancer. Br J Cancer 98(6):1147-1156

Tate JG, Bamford S, Jubb HC, Sondka Z, Beare DM, Bindal N et al (2019) COSMIC: the catalogue of somatic mutations in cancer. Nucleic Acids Res 47(D1):D941-D947

Tomlinson GE, Kappler R (2012) Genetics and epigenetics of hepatoblastoma. Pediatr Blood Cancer 59(5):785-792

Towbin AJ, Meyers RL, Woodley H, Miyazaki O, Weldon CB, Morland B et al (2018) 2017 PRETEXT: radiologic staging system for primary hepatic malignancies of childhood revised for the Paediatric Hepatic International Tumour Trial (PHITT). Pediatr Radiol 48(4):536-554
Tulla M, Berthold F, Graf N, Rutkowski S, von Schweinitz D, Spix $\mathrm{C}$ et al (2015) Incidence, trends, and survival of children with embryonal tumors. Pediatrics 136(3):e623-e632

Vincent KM, Postovit LM (2017) A pan-cancer analysis of secreted Frizzled-related proteins: re-examining their proposed tumour suppressive function. Sci Rep 7:42719

Wang Z, Li R, He Y, Huang S (2018) Effects of secreted frizzledrelated protein 1 on proliferation, migration, invasion, and apoptosis of colorectal cancer cells. Cancer Cell Int 18:48

Wirths O, Waha A, Weggen S, Schirmacher P, Kuhne T, Goodyer CG et al (2003) Overexpression of human Dickkopf-1, an antagonist of wingless/WNT signaling, in human hepatoblastomas and Wilms' tumors. Lab Invest 83(3):429-434

Zheng L, Sun D, Fan W, Zhang Z, Li Q, Jiang T (2015) Diagnostic value of SFRP1 as a favorable predictive and prognostic biomarker in patients with prostate cancer. PLoS ONE 10(2):e0118276

Zucman-Rossi J, Villanueva A, Nault JC, Llovet JM (2015) Genetic landscape and biomarkers of hepatocellular carcinoma. Gastroenterology 149(5):1226-1239 (e4)

Publisher's Note Springer Nature remains neutral with regard to jurisdictional claims in published maps and institutional affiliations. 